\title{
Aplikasi Sistem Informasi Geografis Wisata Islam Melayu di Kota Palembang Berbasis Android
}

Gusmelia Testiana

Fakultas Ilmu Tarbiyah dan Keguruan

Univesitas Islam Negeri Raden Fatah Palembang, Indonesia

Email: gusmeliatestiana_uin@radenfatah.ac.id

\begin{abstract}
Abstrak
Aplikasi Sistem Informasi Geografis Wisata Islam Melayu pada kota Palembang dengan smartphone yang menggunakan sistem operasi Android dapat diimplementasikan pada beberapa jenis smartphone diaantaranya Smartfren Andromax C3, Lenovo S920, Samsung Galaxy Ace, Samsung Galaxy Ace 2, Sony Xperia Neo, Sony Xperia Z Ultra. Masyarakat atau wisatawan dapat dengan mudah memperoleh informasi masjid yang berada di kota Palembang.
\end{abstract}

\begin{abstract}
Application of Malay Muslims Tourism Geographic Information Systems in the city of Palembang with Smartphone that use the Android operating system can be implemented on multiple types of Smartphone including Smartfren Andromax C3, Lenovo S920, the Samsung Galaxy Ace, Samsung Galaxy Ace 2, Sony Xperia Neo, Sony Xperia Z Ultra. Community or tourists can easily obtain information on the mosque in the city of Palembang.
\end{abstract}

Keywords: Information Systems, Malay Muslims Tourism, Android

Perkembangan teknologi yang sangat cepat telah membawa manusia memasuki kehidupan yang berdampingan dengan informasi dan teknologi itu sendiri yang berdampak pada sebagian orang untuk meninggalkan proses penelusuran informasi secara manual yang membutuhkan waktu lebih lama untuk mendapatkan atau menemukan informasi yang diinginkan.

Teknologi informasi yang berkembang saat ini memungkinkan pengelolaan informasi dapat dilakukan secara lebih aktual dan optimal. Penggunaan teknologi informasi bertujuan untuk mencapai efisiensi dalam

Intizar, Vol. 22, No. 1, 2016 
berbagai aspek pengelolaan informasi, yang ditunjukkan dengan kecepatan dan ketepatan waktu pemrosesan, serta ketelitian dan keakuratan informasi. ${ }^{1}$

Kota Palembang sebagai daerah yang mempunyai potensi untuk pengembangan budaya dan religi Islam Melayu mempunyai banyak tempat yang dapat dikunjungi yang mana tempat-tempat tersebut tidak terdokumentasi dengan baik dan para pengunjung sangat sulit untuk mengetahui tempat-tempat wisata religi di kota Palembang. Wisatawan sangat sulit untuk mendapatkan informasi tempat-tempat pelayanan umum khususnya Masjid yang ada di kota Palembang.

Memperkenalkan wisata religi di kota Palembang perlu dilakukan melalui promosi agar dapat menarik perhatian para wisatawan. Promosi dapat dilakukan dengan melalui media, termasuk media online seperti melalui website, mobile dan jejaring sosial. Promosi yang dilakukan dengan menggunakan media online memiliki keuntungan terutama dalam minimum biaya dikeluarkan. Saat ini kota Palembang sudah memiliki web portal untuk mempromosikan pariwisatanya. Web portal tersebut sudah menyediakan sedikit informasi mengenai keunikan objekobjek wisata di kota Palembang.

Akan tetapi, pada saat ini para wisatawan memerlukan informasiinformasi yang lebih terintegrasi, tidak hanya informasi mengenai objek wisatanya saja, tetapi juga informasi mengenai posisi tepatnya tempat wisata itu berada, dan mana tempat yang terdekat. Selain itu, para wisatawan juga lebih suka menggunakan sistem informasi yang sederhana dan interaktif dengan tampilan yang menarik. Seiring dengan kesibukan manusia yang semakin tinggi, perkembangan teknologi mobile pun berkembang sangat pesat.

Dahulu mobile phone hanya digunakan untuk sekedar sms atau melakukan panggilan, tetapi teknologi mobile saat ini dapat melakukan yang jauh lebih besar dari itu. Mobile phone saat ini dapat melakukan akses internet, pushing email, memutar musik dan video dan masih banyak yang lainnya, mobile phone jenis ini disebut smartphone. Smartphone adalah telepon seluler pintar yang mempunyai kemampuan tingkat tinggi dengan fungsi yang menyerupai komputer mini. Smartphone seakan menjadi perangkat yang wajib dimiliki oleh orang-orang dengan mobilitas tinggi yang ingin mengoptimalkan aktivitasnya demi meningkatkan produktivitas mereka. ${ }^{2}$

Salah satu Sistem Operasi yang digunakan pada Smartphone adalah Android. Android adalah sistem operasi milik Google ini memiliki perkembangan yang sangat cepat di pasaran. Pasar pengguna smartphone berbasis android meningkat secara signifikan dalam beberapa tahun terakhir. Dengan adanya salah 
satu teknologi dari google yaitu berupa Google Maps, maka sistem informasi geografis dapat diimplementasikan pada device berbasis Android. Google Maps sangat membantu dalam pengenalan daerah secara cepat dan tepat karena Google Maps menawarkan peta yang dapat diseret dan gambar satelit untuk seluruh dunia. Google Maps merupakan sebuah jasa peta globe virtual dan online disediakan oleh Google.

Penggunaan teknologi ini diharapkan nantinya dapat dibuat sebuah sistem informasi geografis berbasis Android dengan menggunakan Global Positioning System (GPS) yang nantinya dapat membantu wisatawan yang berkunjung ke kota Palembang. Wisatawan hanya cukup mengaksesnya melalui mobile phone mereka digunakan untuk memandu mereka dan selanjutnya dapat menikmati fitur-fitur yang ditawarkan di dalamnya. Permasalahan ini dapat diatasi dengan menerapkan SIG (Sistem Informasi Geografi) sebagai langkah yang tepat untuk mengetahui lokasi obyek wisata religi yang terdapat di kota Palembang.

Peneliti akan mencoba mengembangkan aplikasi mobile yang berbasiskan android dalam pembuatan aplikasi untuk mengatasi permasalahan tersebut. Berdasarkan uraian di atas akan dibangun sebuah aplikasi Sistem Informasi Geografis yang berbasis mobile android, dimana aplikasi ini nantinya memberikan informasi mengenai peta letak wisata religi yang ada di kota Palembang, khususnya informasi tentang fasilitas umum seperti masjid dan informasi lainnya yang berhubungan dengan keislaman.

\section{Sistem Informasi Geografis}

Menurut Aronoff dalam buku Eddy Prahasta, ${ }^{3}$ Sistem Informasi Geografis adalah sistem yang berbasiskan komputer yang digunakan untuk menyimpan dan memanipulasi informasi-informasi geografis. Sistem Informasi Geografis dirancang untuk mengumpulkan, menyimpan dan menganalisis objek-objek dan fenomena di mana lokasi geografi merupakan karakteristik yang penting atau kritis untuk dianalisis.

Dengan demikian Sistem Informasi Geografis merupakan sistem komputer yang memiliki empat kemampuan berikut dalam menangani data yang bereferensi geografi: masukan, manajemen data (penyimpanan dan pemanggilan data), analisis, manipulasi data, dan keluaran.

Sementara menurut ESRI dalam buku Eddy Prahasta, ${ }^{4}$ Sistem Informasi Geografis adalah kumpulan yang terorganisir dari perangkat keras komputer, perangkat lunak, data geografi dan personil yang dirancang secara efesien untuk 
memperoleh, menyimpan, mengupdate, memanipulasi, menganalisis, dan menampilkan semua bentuk informasi yang bereferensi geografi.

Menurut Foote masih dalam buku Eddy Prahasta, Sistem Informasi Geografis merupakan sistem informasi yang dirancang untuk bekerja dengan data yang tereferensi secara spasial atau koordinat-koordinat geografi, dengan kata lain, Sistem Informasi Geografis adalah sistem basis data dengan kemampuankemampuan khusus untuk data yang tereferensi secara geografis berikut sekumpulan operasi-operasi yang mengelola data tersebut.

Sistem Informasi Geografi merupakan sistem berbasis komputer yang digunakan untuk menyimpan dan memanipulasi informasi-informasi geografis. Sistem informasi geografi diciptakan untuk mengumpulkan, menyimpan dan menganalisis obyek atau fenomena dimana lokasi geografis menjadi karakteristik atau kritik penting untuk analisis. Pada awalnya, data geografi hanya disajikan di ataas peta dengan menggunakan simbol, garis, dan warna. Elemen-elemen geometri ini dideskripsikan di dalam legenda-nya misalnya, garis hitam tebal untuk jalan utama, garis hitam tipis untuk jalan sekunder dan jalan-jalan yang berikutnya. Selain itu, berbagai data juga di dapat di-overlay-kan berdasarkan sistem koordinat yang sama.

Akibatnya, sebuah peta menjadi media yang efektif baik sebagai alat presentasi mapun sebagai bank tempat penyimpanan data geografis. Tetapi, media peta masih mengandung kelemahan atau keterbatasan. Informasi-informasi yang tersimpan, diproses dan dipresentasikan dengan suatu cara tertentu, dan biasanya untuk tujuan tertentu pula. Tidak mudah untuk mengubah bentuk presentasi ini, sebuah peta selalu menyediakan gambar atau simbol unsur geografi dengan bentuk yang tetap atau statis meskipun diperlukan untuk kebutuhan yang berbeda. ${ }^{5}$

Jadi Sistem Informasi Geografis ialah sistem yang berbasis komputer yang digunakan untuk menyimpan, memanipulasi, menganalisis dan menampilkan semua bentuk informasi yang berhubungan dengan data spasial di permukaan bumi (geografis).

\section{Islam Melayu}

Islam Melayu merupakan campuran bahasa Melayu, budaya dan adat istiadat Melayu, pengajaran hukum dan nilai-nilai Islam dan sistem yang harus dihargai dan dipraktekkan oleh semua". (Wikipedia). Masjid dalam Al-Qur'an diungkapkan dalam sebutan pertama masjid dan kedua bait. Istilah masjid 
langsung menunjuk kepada pengertian tempat peribadatan umat Islam. Secara lughawi, masjid berarti tempat sujud atau tempat shalat.

Kata Masjid berasal dari kata sajada-yasjudu yang berarti merendahkan diri menyembah. Dalam al-Qur'an kata masjid disebut sebanyak 28 kali, 22 kali dalam bentuk tunggal dan 6 kali dalam bentuk jama'.

Ditinjau dari Dinul Islam bahwa seluruh bumi di mana saja adalah masjid, tempat shalat. Sedangkan pengertian secara khusus masjid adalah tempat atau bangunan yang didirikan untuk melaksanakan ibadah yang memenuhi syarat dan komponen untuk shalat lima waktu (shalat fardhu) dan digunakan untuk shalat Jum'at. Dalam pengertian syar' $i$ masjid adalah sebuah bangunan, tempat ibadah umat Islam terutama sebagai tempat dilangsungkannya shalat jamaah. Sebagai Baitullah masjid adalah tempat turunnya rahmat Allah Swt. dan malaikat.

Kehadiran masjid negara, propinsi, kabupaten/kota, kecamatan dan desa/kelurahan perlu diatur klasifikasinya atau stratanya sehingga akan terjalin ukhuwah islamiah Antara masjid di daerah kecil dengan segala keterbatasannya sampai yang tertinggi yang berada di ibukota propinsi ataupun negara.Perbedaan strata masjid terletak kepada luas masjid dan daya tampungnya serta kesediaan fasilitas pendukungnya. Klasifikasi/strata masjid di Indonesia berdasarkan Keputusan Menteri Agama no 394 tahun 2004 tentang penetapan status Masjid Wilayah, terdiri dari:

1. Masjid Negara

Masjid Negara yaitu masjid yang berada di tingkat pemerintahan pusat/negara dan dibiayai sepenuhnya oleh pemerintah pusat dan hanya satu masjid yaitu masjid Istiglal Jakarta.

2. Masjid Nasional

Masjid Nasional, yaitu masjid di tingkat provinsi yang diajukan oleh Gubernur kepada Menteri Agama untuk dibuatkan keputusan Menteri Agama untuk menjadi Masjid Nasional dengan mencantumkan nama masjid tersebut, dan seluruh anggaran menjadi tanggung jawab Pemerintah Daerah dalam hal ini Gubernur.

3. Masjid Raya.

Masjid Raya merupakan Masjid pada tingkat propinsi dan diajukan melalui Kantor Wilayah Kementerian Agama setempat kepada Gubernur untuk dibuatkan surat keputusan Penetapan Masjid Raya.

4. Masjid Agung

Intizar, Vol. 22, No. 1, 2016 
Masjid yang berada di tingkat Kota/Kabupaten dan diajukan melalui kantor Kementerian Agama setempat kepada Bupati atau Wali Kota untuk dibuatkan surat keputusan penetapan Masjid Agung.

5. Masjid Besar

Masjid besar yaitu Masjid pada tingkat Kecamatan dan diajukan melalui Kepala Kantor Urusan Agama setempat kepada Camat untuk dibuatkan surat keputusan penetapan Masjid Besar.

6. Masjid Jami'

Masjid Jami' yaitu Masjid pada tingkat Desa/Kelurahan. Pendirian bangunan masjid ini umumnya sepenuhnya dibiayai oleh swadaya masyarakat setempat.

7. Masjid yang berada pada lingkungan masysrakat biasanya masjid disebut dengan nama masjid itu sendiri. Pendirian masjid ini sama dengan pada masjid tingkat desa/kelurahan. ${ }^{6}$

\section{Proses Menampilkan Titik-titik Wisata pada Peta}

Proses untuk menampilkan titik-titk wisata pada peta, dijelaskan sebagai berikut. Untuk tiap titik wisata tersimpan pada variabel list Wisata, yang ditampilkan pada peta dengan menggunakan class WisataMarkerOverlay. Class ini merupakan turunan class Itemized Overlay. Melalui class Wisata Marker Overlay, tiap data wisata, ditampilkan dalam bentuk pin pada peta. Class ini juga menangani event, ketika pin disentuh oleh pengguna, sehingga menampilkan dialog info wisata yang berisi foto dan keterangan wisata. Perintah untuk menampilkan titik-titik wisata pada peta terlihat pada kode program berikut

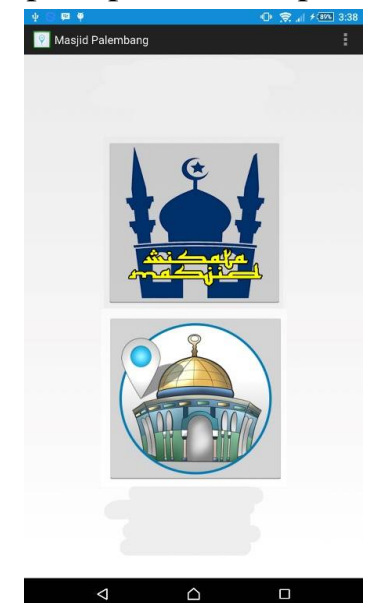

Gambar 4.1 Tampilan Utama Aplikasi

Intizar, Vol. 22, No. 1, 2016 


\section{Gusmelia Testiana}

Pada saat aplikasi dijalankan, maka akan muncul dua tombol utama, yaitu tombol wisata masjid dan tombol cari lokasi masjid.

Pada tombol wisata masjid berisi masjid-masjid bersejarah di kota Palembang yaitu Masjid Agung, Masjid Ki Merogan, Masjid Lawang Kidul dan Masjid Suro Muhammadiyah.

Tombol cari lokasi masjid digunakan untuk mengetahui lokasi sebuah masjid yang ada di kota Palembang berikut dengan rute terpendek untuk menuju laksi masjid dari posisi saat ini.

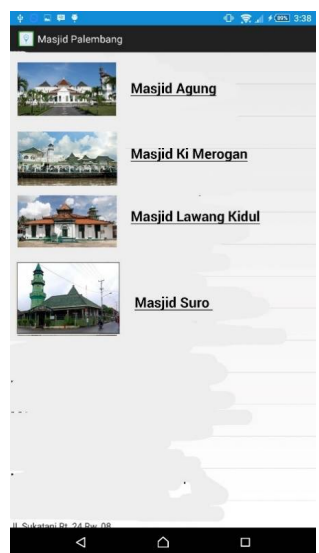

Gambar 4.2 Daftar masjid bersejarah di Palembang

Setelah memilih tombol pertama, maka akan tampil daftar masjid-masjid bersejarah yang ada di kota Palembang. Masing-masing masjid dapat dipilih untuk melihat detail dan sejarah masjid beserta foto-foto masjid tersebut.

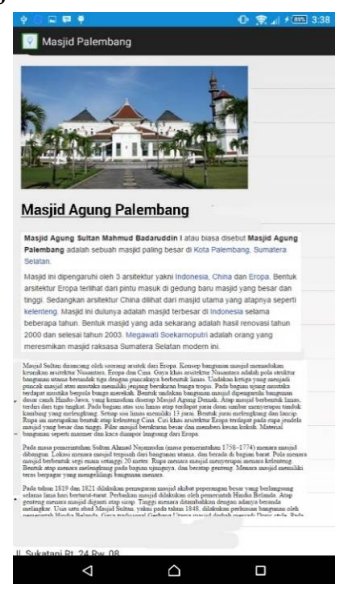

Gambar 4.3 Informasi sejarah Masjid Agung Palembang

Intizar, Vol. 22, No. 1, 2016 


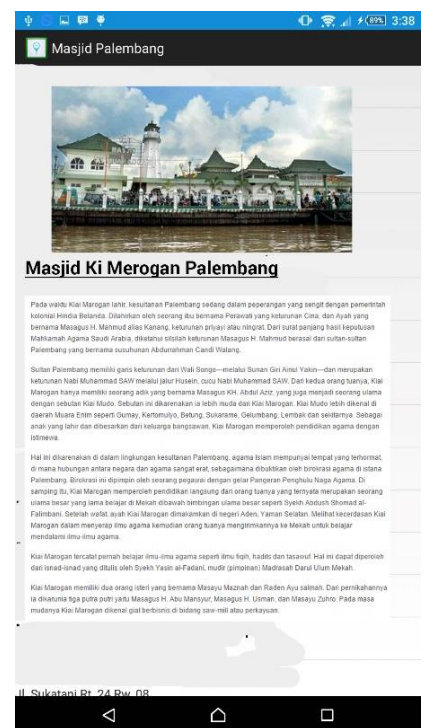

Gambar 4.4 Informasi sejarah Ki Merogan

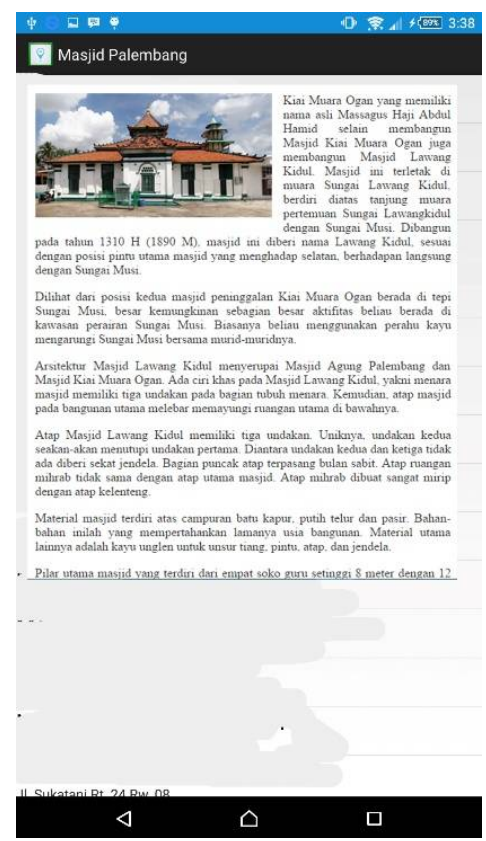

Gambar 4.5 Informasi sejarah Masjid Lawang Kidung

Intizar, Vol. 22, No. 1, 2016 


\section{Gusmelia Testiana}

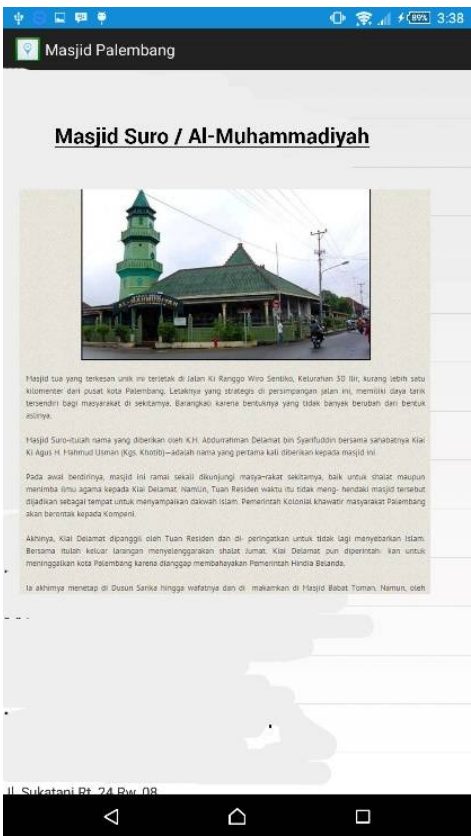

Gambar 4.6 Informasi sejarah Masjid Suro Muhammadiyah

Jika gambar masjid dipilih, maka aplikasi akan menampilkan lokasi dari masjid tersebut di peta dan memberikan petujuk rute terdekat dari posisi saat ini.

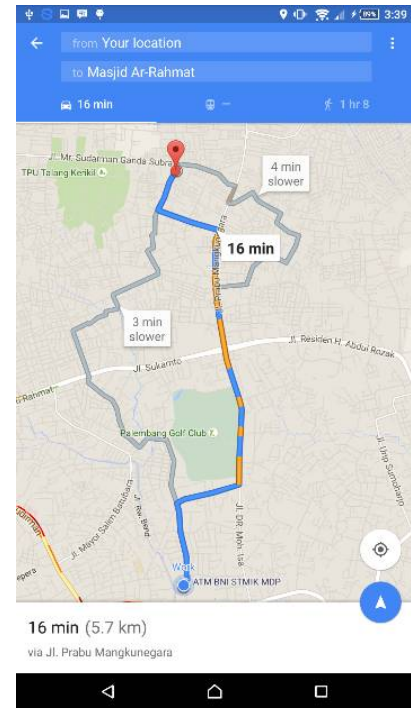

Gambar 4.7 Lokasi dan rute menuju masjid bersejarah

Intizar, Vol. 22, No. 1, 2016 
Setelah tombol pencarian lokasi masjid dipilih, maka akan tampil daftar masjid-masjid yang ada di kota Palembang.

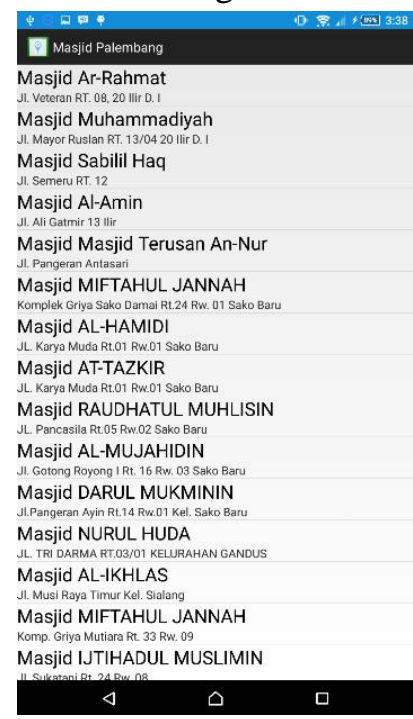

Gambar 4.8 Daftar masjid di kota Palembang

Daftar ini berisi masjid-masjid yang ada di kota Palembang. Masingmasing masjid bisa dipilih untuk pencarian lokasinya di peta.

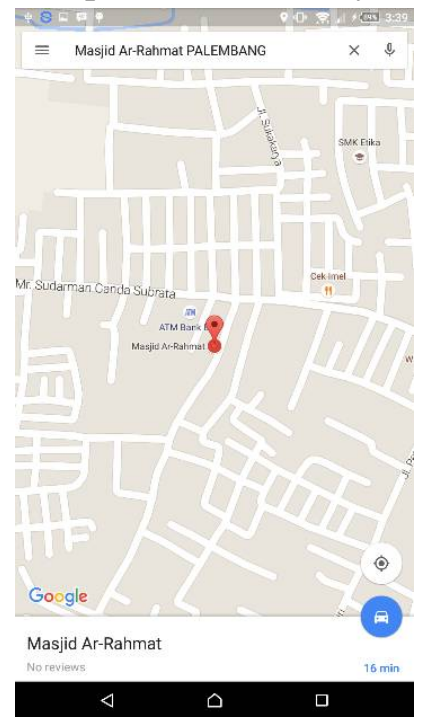

Gambar 4.9 Lokasi masjid di peta

Intizar, Vol. 22, No. 1, 2016 


\section{Gusmelia Testiana}

Pada tampilan lokasi masjid dalam peta tersebut terdapat sebuah tombol unt melakukan pencarian rute terpendek dari lokasi sekarang berada ke lokasi masjid yang ditunjukkan oleh pin berwarna merah.

Jika tombol tersebut dipilih, maka dilakukan proses pencarian rute terpendek dan akan ditampilkan di peta.

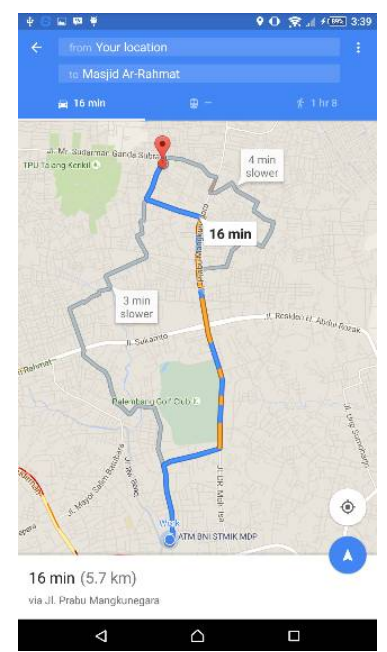

Gambar 4.10 Hasil pencarian rute terpendek

\section{Hasil Tampilan}

Pada saat aplikasi dijalankan, maka akan muncul dua tombol utama, yaitu tombol wisata masjid dan tombol cari lokasi masjid. Pada tombol wisata masjid berisi masjid-masjid bersejarah di kota Palembang yaitu Masjid Agung, Masjid Ki Merogan, Masjid Lawang Kidul dan Masjid Suro Muhammadiyah. Tombol cari lokasi masjid digunakan untuk mengetahui lokasi sebuah masjid yang ada di kota Palembang berikut dengan rute terpendek untuk menuju lokasi masjid dari posisi saat ini.

Setelah memilih tombol pertama, maka akan tampil daftar masjid-masjid bersejarah yang ada di kota Palembang. Masing-masing masjid dapat dipilih untuk melihat detail dan sejarah masjid beserta foto-foto masjid tersebut.

Tampilan informasi masjid bersejarah. Jika gambar masjid dipilih, maka aplikasi akan menampilkan lokasi dari masjid tersebut di peta dan memberikan petujuk rute terdekat dari posisi saat ini. Setelah tombol pencarian lokasi masjid dipilih, maka akan tampil daftar masjid-masjid yang ada di kota Palembang.

Intizar, Vol. 22, No. 1, 2016 
Daftar ini berisi masjid-masjid yang ada di kota Palembang. Masingmasing masjid bisa dipilih untuk pencarian lokasinya di peta. Pada tampilan lokasi masjid dalam peta tersebut terdapat sebuah tombol untuk melakukan pencarian rute terpendek dari lokasi sekarang berada ke lokasi masjid yang ditunjukkan oleh pin berwarna merah. Jika tombol tersebut dipilih, maka dilakukan proses pencarian rute terpendek dan akan ditampilkan di peta. ${ }^{7}$

\section{Hasil Pengujian}

Pengujian aplikasi Masjid Palembang dilakukan menggunakan perangkat smartphone Sony Xperia Z Ultra bersistem operasi Android versi Lollipop (5.0.2). Hasil pengujian berkaitan dengan berbagai kriteria pada prosedur pengujian. Tahap pertama adalah pengujian terhadap waktu yang diperlukan dalam menampilkan setiap fungsi dan fitur yang terdapat pada aplikasi, antara lain fungsi navigasi peta, lokasi terdekat, informasi masjid bersejarah, dan beberapa fungsi lainnya.

Dalam pengujian ini dilakukan dengan menggunakan tiga jenis koneksi yaitu WLAN (atau lebih dikenal dengan Wi-Fi) melalui jaringan Fiber Optic 10Mbps, 2G, dan 3.5G. Provider yang digunakan pada pengujian aplikasi adalah Telkomsel. Berikut adalah hasil pengujian berdasarkan koneksi internet pada aplikasi Masjid Palembang.

\section{Pengujian Pengguna}

Pengujian ini dilakukan secara objektif terhadap kegunaan aplikasi Masjid Palembang kepada user melalui kuisioner 20 pengguna smartphone Android yang menggunakan aplikasi Masjid Palembang. Pada pengujian aplikasi ini dilakukan dengan menginstalasi aplikasi ke perangkat smartphone Android dengan merk dan versi sistem operasi yang berbeda. Setelah itu mengajukan pertanyaan ke user mengenai pemakaian aplikasi. Responden terdiri dari 10 pria dan 10 wanita, usia antara 20 - 35 tahun dan tingkat pendidikan SMA - S2.

Berikut ini merupakan hasil dari kuestioner langsung kepada user mengenai pemakaian aplikasi Masjid Palembang.

1. Bagaimana dengan ketersediaan data pada aplikasi Masjid Palembang?

Berdasarkan presentase di atas, maka dapat disimpulkan bahwa sebanyak 50\% responden menyatakan aplikasi Masjid Palembang memiliki ketersediaan data yang lengkap, serta 30\% (sangat lengkap) dan 20\% (cukup lengkap). 
2. Apakah posisi user sudah sesuai dengan pembacaan posisi aplikasi?

Berdasarkan data di atas, dinyatakan bahwa aplikasi Masjid Palembang memiliki kesesuaian pembacaan posisi sebesar $80 \%$ atau sesuai.

3. Apakah fitur yang disediakan aplikasi dapat dimengerti dan berjalan dengan baik?

Berdasarkan presentase hasil wawancara diatas, maka dapat disimpulkan bahwa sebanyak 60\% responden menyatakan aplikasi Masjid Palembang dapat berjalan dengan baik.

4. Apakah posisi masjid sudah mempresentasikan posisi sebenarnya?

Berdasarkan presentase hasil wawancara diatas, maka dapat disimpulkan bahwa sebanyak $80 \%$ responden menyatakan aplikasi Masjid Palembang dapat dengan sesuai mempresentasikan posisi masjid.

5. Bagaimana dengan tingkat kebutuhan terhadap aplikasi persebaran masjid di Kota Palembang?

Berdasarkan data presentase diatas, maka dapat disimpulkan bahwa sebanyak $80 \%$ responden menyatakan aplikasi Masjid Palembang dapat sangat membantu dalam memberikan informasi persebaran masjid di Kota Palembang.

6. Bagaimana dengan tampilan atau user interface aplikasi Masjid Palembang? Berdasarkan presentase di atas, maka dapat disimpulkan bahwa sebanyak $70 \%$ responden menyatakan aplikasi Masjid Palembang memiliki tampilan atau user interface yang menarik.

\section{Hasil Keberhasilan Instalasi}

Tahap pengujian selanjutnya adalah dengan melakukan instalasipada beberapa merk/tipe smartphone bersistem operasi Android. Berikut adalah tabel hasil pengujian instalasi pada smartphone Android.

Tabel 1

Hasil Pengujian Instalasi pada Smartphone

\begin{tabular}{|c|l|c|c|}
\hline No & Merk/Tipe Smartphone & Versi Sistem Operasi & Instalasi \\
\hline 1 & Smartfren Andromax C3 & Jelly Bean & Berhasil \\
\hline 2 & Lenovo S920 & Kitkat & Berhasil \\
\hline
\end{tabular}

Intizar, Vol. 22, No. 1, 2016 


\begin{tabular}{|c|l|c|c|}
\hline 3 & Samsung Galaxy Ace & Ginger Bread & Berhasil \\
\hline 4 & Samsung Galaxy Ace 2 & Jelly Bean & Berhasil \\
\hline 5 & Sony Xperia Neo & Jelly Bean & Berhasil \\
\hline 6 & Sony Xperia Z Ultra & Lollipop & Berhasil \\
\hline
\end{tabular}

Pada tabel di atas dapat diketahui bahwa aplikasi Masjid Palembang dapat diinstalasi dengan baik pada beberapa merk/tipe smartphone yang berbeda. Kemudian juga pada tabel di atas menunjukkan bahwa aplikasi Masjid Palembang berhasil diinstalasi pada tiga jenis versi sistem operasi Android yang berbeda. Versi sistem operasi Android yang berhasil dalam pengujian tersebut antara lain sistem operasi dengan versi Ginger Bread (2.3-2.3.7) sebanyak 1 buah smartphone, Jelly Bean (4.1-4.3) sebanyak 3 buah smartphone, Kitkat (4.4) sebanyak 1 buah smartphone dan Lollipop (5.0.1) sebanyak 1 buah.

\section{Analisis Ketepatan Hasil}

Analisis ini dilakukan untuk memastikan ketepatan hasil dari perhitungan data aplikasi untuk membandingkan jarak A-GPS yang ditampilkan pada aplikasi melalui jarak yang didapat dari distance measurement tool pada Google Maps.

Jarak-jarak tersebut adalah hasil perhitungan jarak menggunakan haversine formula. Berikut adalah perbandingan jarak yang didapat melalui $A$ GPS dan jarak dari distance measurement tool pada Google Maps berdasarkan pembacaan posisi di Jalan Zainal Fikri Raden Fatah Palembang.

Dapat disimpulkan bahwa perbandingan jarak memiliki kesalahan ratarata 0,1675 kilometer atau 167,5 meter. Hal ini dapat disebabkan oleh berbagai hal seperti kondisi sinyal provider yang tidak stabil di lokasi, sehingga membuat pembacaan lokasi melalui LBS menjadi tidak akurat dan berbeda dengan kondisi sebenarnya dilapangan.

Selanjutnya adalah analisis pada pembacaan posisi yang dilakukan dengan cara membandingkan hasil pembacaan posisi dengan menggunakan GPS handheld, Google Maps, dan A-GPS pada smartphone pada suatu lokasi yang sama yaitu Gedung Tarbiyah UIN Raden Fatah Palembang.

1. Pertama pembacaan lokasi menggunakan GPS handheld. Dari pengukuran tersebut didapatkan koordinat $-2^{\circ} 57^{\prime} 47.0226^{\prime \prime}$ dan $104^{\circ} 44^{\prime} 55.4928^{\prime \prime}$ atau

Intizar, Vol. 22, No. 1, 2016 
jika diubah ke koordinat default Google Maps yaitu -2.962848, 104.748286.

2. Kemudian pada posisi yang sama, dilakukan pembacaan posisi dengan menggunakan aplikasi A-GPS pada smartphone Android. Hasil pembacaan posisi yang didapat adalah -2.962824, 104.748123.

3. Berikutnya adalah melakukan pembacaan posisi melalui Google Maps pada smartphone Android. Hasil pembacaan posisi yang didapat adalah 2.962831, 104.748544.

4. Langkah berikutnya adalah membandingkan selisih setiap hasil pembacaan posisi. Sebelumnya lakukan transformasi koordinat yang telah didapat kedalam sistem koordinat UTM, untuk memudahkan dalam menghitung selisih antar koordinat.

Hasil transformasi koordinat geografis ke UTM

$\begin{array}{ll}\text { GPS handheld } & =472027.6350665776,9672510.168314517 \\ \text { A-GPS } & =472009.5205532114,9672512.817017803 \\ \text { Google Maps } & =472056.30573757045,9672512.053901156\end{array}$

Dari hasil pengukuran tersebut, dapat dilihat bahwa hasil pengukuran melalui A-GPS dan Google Maps memiliki akurasi yang hampir sama, namun memiliki perbedaan yang cukup beragam dengan hasil pengukuran melalui GPS handheld. Pada tabel diatas, pengukuran pertama antara A-GPS dan Google Maps memiliki selisih sebesar 28,537 meter. Meskipun demikian dengan selisih nilai tersebut, tentunya masih dapat dipergunakan untuk keperluan navigasi yang tidak terlalu membutuhkan akurasi tinggi.

Kemudian dilakukan juga pengukuran untuk membandingkan selisih jarak antara beberapa koordinat BM (Benchmark) dan pembacaan melalui Google Maps serta A-GPS dengan menggunakan metode yang sama. Koordinat BM yang digunakan adalah koordinat Tamansari Kenten 2 Q.22.

\section{Kesimpulan}

Berdasarkan penjelasan di atas, dapat disimpulkan bahwa aplikasi Sistem Informasi Geografis Wisata Islam Melayu pada kota Palembang dengan smartphone yang menggunakan sistem operasi Android dapat diimplementasikan pada beberapa jenis smartphone diaantaranya Smartfren Andromax C3, Lenovo S920, Samsung Galaxy Ace, Samsung Galaxy Ace 2, Sony Xperia Neo, Sony

Intizar, Vol. 22, No. 1, 2016 
Aplikasi Sistem Informasi Geografis ...

Xperia Z Ultra. Masyarakat atau wisatawan dapat dengan mudah memperoleh informasi masjid yang berada di kota Palembang.

Intizar, Vol. 22, No. 1, 2016 


\section{Endnote}

${ }^{1}$ Adi Nugroho, Analisis dan Perancangan Sistem Informasi Dengan Metodologi Berorientasi Objek, (Bandung: Informatika, 2005),

${ }^{2}$ Elvinaro Ardianto, Metodologi Penelitian untuk Public Relations Kuantitatif dan Kualitatif, (Bandung: Simbiosa Rekatama Media, 2011),

${ }^{3}$ Budi Darytamo dkk, Pemrograman Berorientasi Objek dengan Java 2 Platform Micro Edition (J2ME), (Bandung: ITB., 2007), 2006),

${ }^{4}$ Juan Chamero, Dijkstra Algorithm As a Dynamic, (Spain: Programming Strategy,

${ }^{5}$ Ivar Jacobson, Magnus Christerson, Patrik Jonson, and Gunnar Overgaard, ObjectOriented Software Engineering: A Use Case Driven Approach. (Addison-Wesley, 1992),

${ }^{6}$ Stephanus Hermawan S, "Mudah Membuat Aplikasi Android”, (Yogyakarta: Andi Offset, 2011), t.th),

${ }^{7}$ Rachmad Hakim S dan Sutarto, "Mastering Java", (t.k: Elex Media Komputindo,

\section{Daftar Pustaka}

Adi Nugroho. (2005). Analisis dan Perancangan Sistem Informasi Dengan Metodologi Berorientasi Objek. Bandung: Informatika.

Ardianto, Elvinaro. (2011). Metodologi Penelitian untuk Public Relations Kuantitatif dan Kualitatif. Bandung: Simbiosa Rekatama Media.

Chamero, Juan. (2006). Dijkstra Algorithm As a Dynamic. Spain: Programming Strategy.

Darytamo, Budi dkk. (2007). Pemrograman Berorientasi Objek dengan Java 2 Platform Micro Edition (J2ME). Bandung: ITB.

Fathansyah. (2007). Basis Data. Bandung: Informatika.

Hakim S, Rachmad dan Sutarto. (t.th). "Mastering Java". T.t: Elex Media Komputindo.

Hermawan S, Stephanus. (2011). “Mudah Membuat Aplikasi Android”. Yogyakarta : Andi Offset.

Ivar Jacobson, Magnus Christerson, Patrik Jonson, and Gunnar Overgaard, (1992). Object-Oriented Software Engineering: A Use Case Driven Approach. Addison-Wesley. 